\title{
Diurnal and tidal vertical migration of pre- settlement King George whiting Sillaginodes punctata in relation to feeding and vertical distribution of prey in a temperate bay
}

\author{
Gregory P. Jenkins $^{1, *}$, Dirk C. Welsford ${ }^{2}$, Michael J. Keough ${ }^{2}$, Paul A. Hamer ${ }^{1}$ \\ ${ }^{1}$ Marine and Freshwater Resources Institute, PO Box 114, Queenscliff, Victoria 3225, Australia \\ ${ }^{2}$ Department of Zoology, University of Melbourne, Parkville, Victoria 3052, Australia
}

\begin{abstract}
Vertically stratified sampling was undertaken for pre-settlement King George whiting Sillaginodes punctata at 1 site in 1995 and 4 sites in 1996, in Port Phillip Bay, Australia. In 1995, 3 depth strata were sampled: surface, $2.5-3.0 \mathrm{~m}$, and $5.0-5.5 \mathrm{~m}$, in a total water depth of 7 to $8 \mathrm{~m}$. Sampling was conducted on 17 dates and encompassed all combinations of day and night, and ebb and flood tide. A total of 3 , or in one case 4, replicate samples were taken at each depth. On 4 occasions a smaller zooplankton net was deployed at the same time as the ichthyoplankton net. Pre-settlement $S$. punctata showed 'reverse' diurnal vertical migration, with concentration near the surface during the day and diffusion through the water column at night. A much weaker tidal migration was also detected, with larvae slightly higher in the water column on flood tides. Pre-settlement $S$. punctata only fed in daylight and zooplankton taxa that were eaten did not show vertical stratification during daytime. In 1996, 4 sites were sampled at a minimum of $10 \mathrm{~m}$ depth, and an additional depth stratum, 7.5-8.0 m, was sampled. Smaller numbers of larvae were collected in 1996 compared with 1995. All larvae collected in daytime were in the surface stratum, whilst at night larvae were spread through the water column. Although diurnal vertical migration was not a response to prey migrations, daytime ascent of larvae may have occurred to find adequate light levels for visual predation. The generality of tidal migration is unclear, and may have been a result of local factors. Both diurnal and tidal migration would be expected to strongly influence transport of pre-settlement $S$. punctata to seagrass beds in Port Phillip Bay.
\end{abstract}

KEY WORDS: Vertical distribution - Diurnal vertical migration - Pre-settlement fish - Selective tidal transport . Sillaginodes punctata

\section{INTRODUCTION}

Many marine organisms have a bipartite life-cycle where a dispersive larval stage separates benthic adults in space and time. Variability in dispersal due to variation in planktonic processes such as larval duration, mortality, regional hydrodynamics, and larval behaviour may lead to spatio-temporal patchiness in recruitment. Thus, understanding the dynamics oper-

\footnotetext{
•E-mail: g.jenkins@mafri.com.au
}

ating on larvae may, in turn, lead to a greater understanding of the causes of variability seen in, and enhance predictive models of, marine populations.

At the simplest level, dispersal may be considered to be a function of the hydrodynamic regime under which larvae exist, and the time the larva spends in the plankton (Scheltema 1986). This approach may be reasonable in some cases, such as in small, slow swimming, neutrally buoyant larvae of molluscs (McShane et al. 1988) and starfish (Black \& Moran 1991). However, for groups with actively swimming, behaviourally complex larvae such as decapods and fish, behaviour 


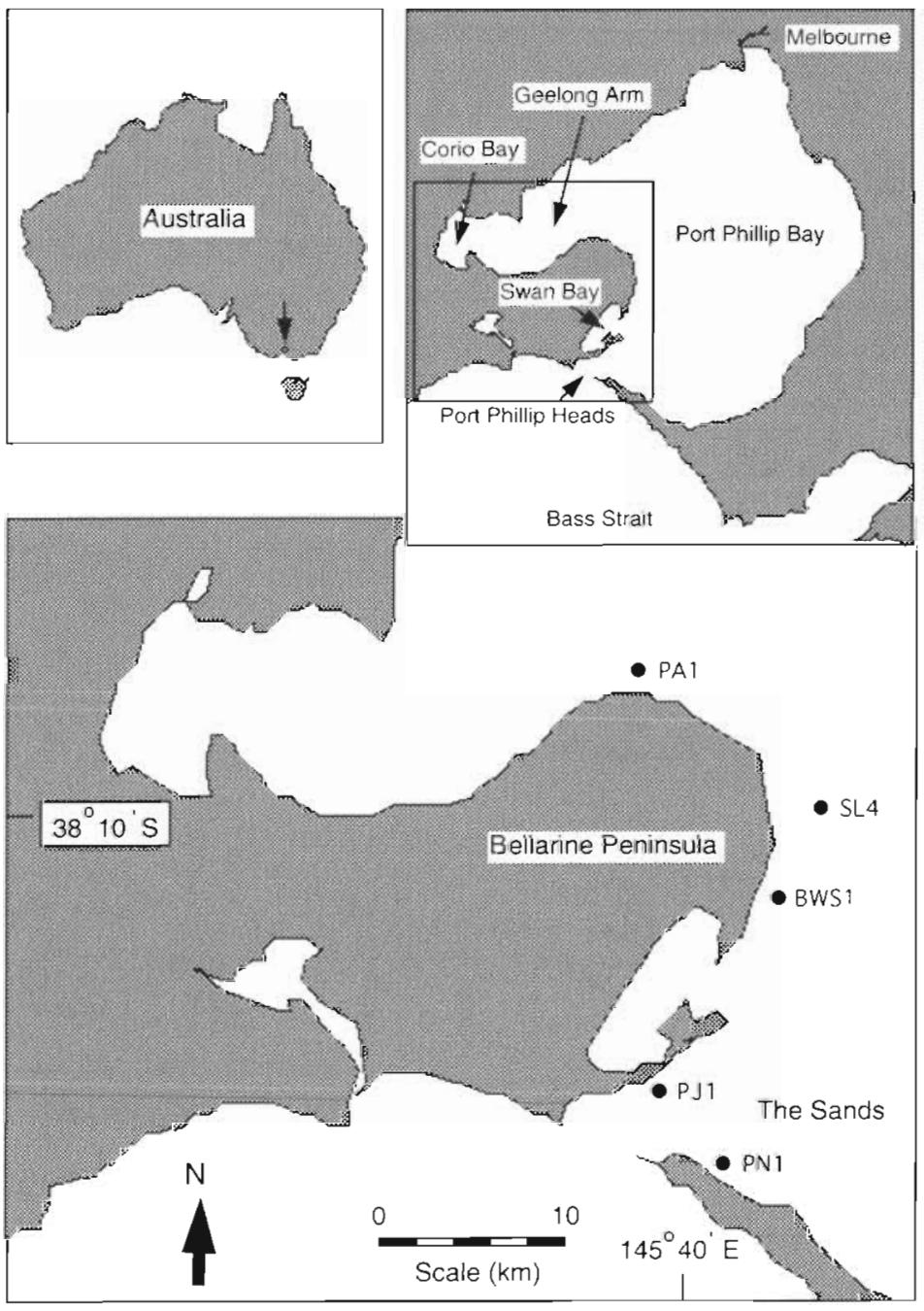

Fig. 1 Sampling sites in the Bellarine Peninsula region of Port Phillip Bay, Victoria, Australia. Insets: location of the Bellarine Peninsula in Port Phillip Bay and location of Port Phillip Bay on the Australjan coast

dispersal-time relationship (Keough \& Black 1996).

The most commonly recognised form of vertical migration is 'diurnal vertical' or 'nocturnal' migration where plankters distribute at the surface at night and migrate deeper during the day (Hutchinson 1967. Haney 1988); however, 'reverse' diurnal migration where animals move downward at night and upwards during the day is also common (Haney 1988, Chae \& Nishida 1995). A range of vertical migratory behaviours has been recorded between these extremes (Haney 1988) and a full range of migratory behaviour can be expressed in the same population (Ohman 1990). Fish larvae also show a range of vertical migratory behaviour (Neilson \& Perry 1990), from nocturnal ascent (Smith et al. 1978, Kendall \& Naplin 1981, Boehlert et al. 1985) to nocturnal descent (Boehlert et al. 1985, Yamashita et al. 1985, Sogard et al. 1987, Davis et al. 1990, Heath et al. 1991, Lyczkowski-Shultz \& Steen 1991). In fish larvae, diel differences often tend to result from distinct depth preference during the day in comparison with random distribution at night or 'nocturnal diffusion' (Brewer \& Kleppel 1986, Davis et al. 1990, Leis 1991, Haldorson et al. 1993).

One form of vertical migration that has great potential to influence dispersal, and particularly recruitment to nearshore habitats, is a form of tidal vertical migration-selective tidal transport (Boehlert \& Mundy 1988, Neilson \& Perry 1990). Migration to nearshore habitats may be facilitated by orientation near or on the bottom during ebb tides and rising into the water column on flood tides (Creutzberg 1961, Holt et al. 1989,

would be expected to modify the pattern predicted for the 'passive' case.

The most obvious and well studied form of larval behaviour that might influence dispersal is vertical. migration (Hutchinson 1967, Haney 1988). Vertical migration has great potential to influence horizontal dispersal because horizontal current profiles vary with depth and, within a moderate horizontal current, residual vertical advection may be as little as $0.01 \mathrm{~cm} \mathrm{~s}^{-1}$ (Mileikovsky 1973). This may be compared with typical horizontal currents of a few $\mathrm{cm} \mathrm{s}^{-1}$ up to extremes of several $\mathrm{m} \mathrm{s}^{-1}$ as encountered in tidal jets (Kingsford 1990, Black et al. 1993). Thus, even weak swimming larvae may be capable of vertical movement between strata of different horizontal current speeds and possibly direction, and therefore may generate noise in any
Rowe \& Epifanio 1994). There is also commonly an interaction with diurnal changes; for example, larvae may be found higher in the water column on nighttime, flood tides (Weinstein et al. 1980, Rijnsdorp et al. 1985).

The King George whiting Sillaginodes punctata (Perciformes: Sillaginidae) is an important commercial and recreational fish species in southern Australia (Kailola et al. 1993). Adult fish live in coastal waters, spawning offshore in autumn and early winter (Jenkins \& May 1994). The duration of the larval stage is long and variable, ranging from 80 to $170 \mathrm{~d}$, and larvae reach a size of 15 to $20 \mathrm{~mm}$ (Jenkins \& May 1994, Fowler \& Short 1996). In spring, late-stage larvae enter shallow bays and inlets containing their juvenile habitat, shallow macrophyte beds (Jenkins et al. 1996). 
Some success has been achieved in modelling the temporal variability in transport of whiting larvae to Port Phillip Bay (Jenkins \& Black 1994), and their supply to juvenile habitats within the bay (Jenkins et al, 1996 , Jenkins et al. 1997). The modelling includes passive horizontal advection and random vertical movement of particles (Black et al. 1993). In order to develop a more realistic model of larval dispersal, incorporation of any significant behavioural attributes is required. In the present study, we investigate the patterns of vertical distribution of late-stage larvae of $S$, punctata in relation to time of day and tidal phase in Port Phillip Bay. For 1 site, we compared vertical distributions of larvae between night and day and tidal phases, and then sampled additional sites to test whether vertical migration was consistent spatially. We also investigate the vertical distribution of potential food organisms to test whether vertical stratification of prey might influence any patterns observed.

\section{MATERIAL AND METHODS}

Study area. Port Phillip Bay is a large, semienclosed, predominantly tidal embayment linked to the oceanic waters of Bass Strait by a narrow entrance (Fig. 1). The hydrodynamics are characterised by an entrance region, where fast $\left(3 \mathrm{~m} \mathrm{~s}^{-1}\right)$ ebb and flood jets dominate the circulation, a large flood-tidal delta, known as the Sands region, where strong currents occur in the major channels, and an inner zone, where tidal currents are weak (Black et al. 1993). On the western side of Port Phillip Bay, tidal currents drop to below $10 \mathrm{~cm} \mathrm{~s}^{-1}$ at about the entrance to the Geelong Arm. Tides are semidiurnal and the range inside the bay is less than $1 \mathrm{~m}$.

The sampling site in 1995 (BWS1) was in the Sands region of Port Phillip Bay close to the western shoreline (Fig. 1). The site was located in a minor channel (Coles Channel) of approximately 7 to $8 \mathrm{~m}$ depth, depending on tide, and with an average width of approximately $200 \mathrm{~m}$. The site was chosen because it had consistently yielded high abundances of pre-settlement Sillaginodes punctata over $3 \mathrm{yr}$ of sampling (G. Jenkins unpubl. data). In 1996, sampling was conducted at 4 sites that were at least $10 \mathrm{~m}$ in depth (Fig. 1), to test the consistency of vertical distribution patterns in space.

All sites were in the 'exchange' zone where there is considerable exchange of water with Bass Strait (Anonymous 1973). Thus, the salinity was essentially marine, water temperature was similar to Bass Strait (12 to $16^{\circ} \mathrm{C}$ over the sampling period), and turbidity was relatively low but increased episodically due to runoff or strong winds. No strong stratification occurs in this zone in the spring period (Black et al. 1993).

Ichthyoplankton sampling methods. In 1995, sampling for Sillaginodes punctata larvae was conducted on 17 dates between 12 September and 16 November. Sampling excursions were chosen to encompass all combinations of day and night, and ebb and flood tides (Table 1). On each sampling date, 3 hauls were made at each of 3 depths: surface (top of net just under surface), mid (top of net 2.5 to $3.0 \mathrm{~m}$ below surface) and bottom (top of net 5.0 to $5.5 \mathrm{~m}$ below surface). Three

Table 1. Sillaginodes punctata. Total number and mean density with respect to depth for sampling in 1995. N: number of replicate hauls per depth. S: surface; $M$ : mid; B: bottom

\begin{tabular}{|c|c|c|c|c|c|c|c|c|}
\hline \multirow[t]{2}{*}{ Date } & \multirow[t]{2}{*}{$\begin{array}{l}\text { Diurnal-tidal } \\
\text { state }\end{array}$} & \multirow[t]{2}{*}{$\mathrm{N}$} & \multicolumn{3}{|c|}{ Number } & \multicolumn{3}{|c|}{$\begin{array}{l}\text { Mean density per haul } \\
\text { (no. } 1000 \mathrm{~m}^{-3} \text { ) }\end{array}$} \\
\hline & & & $S$ & M & $\mathrm{B}$ & $\mathrm{S}$ & M & B \\
\hline $12 \mathrm{Sep}$ & Day-flood & 3 & 17 & 2 & 0 & 11.85 & 1.39 & 0 \\
\hline $15 \mathrm{Sep}$ & Day-flood & 3 & 28 & 1 & 0 & 18.05 & 0.67 & 0 \\
\hline $19 \mathrm{Sep}$ & Day-ebb & 3 & 4 & 1 & 0 & 2.75 & 0.63 & 0 \\
\hline 22 Sep & Day-ebb & 3 & 4 & 5 & 0 & 2.80 & 3.33 & 0 \\
\hline $26 \mathrm{Sep}$ & Day-flood & 3 & 18 & 0 & 0 & 13.0 & 0 & 0 \\
\hline $27 \mathrm{Sep}$ & Night-ebb & 3 & 32 & 43 & 27 & 21.64 & 28.62 & 18.01 \\
\hline $2 \mathrm{Oct}$ & Day-ebb & 3 & 1 & 0 & 0 & 0.66 & 0 & 0 \\
\hline 4 Oct & Night-ebb & 3 & 23 & 23 & 44 & 14.76 & 14.94 & 28.31 \\
\hline 6 Oct & Night-flood & 3 & 69 & 26 & 32 & 31.84 & 19.52 & 21.62 \\
\hline $8 \mathrm{Oct}$ & Night-flood & 3 & 14 & 6 & 2 & 10.40 & 4.27 & 1.33 \\
\hline $15 \mathrm{Oct}$ & Night-ebb & 3 & 45 & 45 & 213 & 34.35 & 32.13 & 150.17 \\
\hline $18 \mathrm{Oct}$ & Day-ebb & 3 & 19 & 5 & 1 & 13.33 & 3.35 & 0.63 \\
\hline $24 \mathrm{Oct}$ & Night-flood & 4 & 42 & 25 & 33 & 21.54 & 13.50 & 16.12 \\
\hline 26 Oct & Day-flood & 3 & 74 & 1 & 0 & 62.37 & 0.69 & 0 \\
\hline $3 \mathrm{Nov}$ & Day-ebb & 3 & 55 & 5 & 1 & 39.40 & 3.42 & 0.71 \\
\hline $8 \mathrm{Nov}$ & Day-flood & 3 & 9 & 1 & 0 & 8.13 & 0.97 & 0 \\
\hline $16 \mathrm{Nov}$ & Day-ebb & 3 & 28 & 0 & 0 & 21.40 & 0 & 0 \\
\hline
\end{tabular}


replicate hauls were made at each depth, except on 24 October when 4 hauls were made. Replicates alternated amongst the 3 depths, with the order of alternation chosen haphazardly on each separate sampling excursion. Sampling began within 0 to 3 h of the beginning of the respective tidal phase. When sampling at night, sampling began within 0 to $3 \mathrm{~h}$ of the onset of darkness. The total sampling period was approximately $4.5 \mathrm{~h}$.

In 1996, sampling was conducted on 11 dates between 17 September and 12 November, spread across 4 additional sites (Table 2). The sampling protocol was the same as in 1995 but with an additional depth stratum sampled (top of net 7.5 to $8.0 \mathrm{~m}$ below surface). Sampling was conducted during daylight with the exception of 2 night sampling trips at site PJ1 (Table 2). Unlike 1995, sampling was random with respect to tidal flow.

For ichthyoplankton sampling, a plankton net of $1 \mathrm{~mm}^{2}$ mesh and $4 \mathrm{~m}$ length was attached to a $1 \times 1 \mathrm{~m}$ square frame. The towing cable was attached to a chain bridle attached to the top corners of the net frame. A $16 \mathrm{~kg}$ depressor was attached to a chain bridle on the bottom of the net. This configuration meant that the towing cable and bridles did not impinge on the mouth of the net. The towing speed was approximately $1 \mathrm{~m} \mathrm{~s}^{-1}$, producing an angle of attack of the net of approximately $30^{\circ}$ and an effective mouth area of $0.9 \mathrm{~m}^{2}$. Estimates of volumes filtered were based on a General Dynamics mechanical flow-meter, calibrated before sampling and suspended in the mouth of the net.

Each of the replicate samples involved fishing the net for 15 min at the chosen depth. The depth of the net was estimated from the length of towing cable and the angle of the cable (approximately $55^{\circ}$ to the horizontal). The depth of the net was checked a number of times during each tow by sending a messenger weight down to the net with a mechanical depth gauge attached that measured maximum depth. The length of cable deployed was adjusted to achieve the correct depth where necessary. Methods for deploying the net were designed to minimise cross-contamination amongst sampling strata. For mid and bottom tows the net was lowered to the required depth with the vessel stationary, and then further cable was let out while the boat accelerated to towing speed and the predetermined length of cable was deployed. The timing of the tow began when the vessel started accelerating. The boat was stopped for net retrieval. Net deployment and retrieval took no more than $1 \mathrm{~min}$ for the deepest hauls. For surface hauls, a combination of the davit arm extending from the side of the vessel and a circular tow path kept the net from being influenced by propeller turbulence and the vessel wake.

Zooplankton sampling methods. Zooplankton sampling was conducted concurrently with the ichthyoplankton sampling on the final 4 days of sampling in 1995 (Table 1). Samples were collected with a $253 \mu \mathrm{m}$ plankton net attached to a $30 \mathrm{~cm}$ diameter ring. Estimates of volumes filtered were based on an Ocean Instruments mechanical flow-meter, calibrated before sampling and suspended in the mouth of the net. Consecutive zooplankton hauls of 2 min duration were taken at 4 and 11 min after the beginning of the ichthyoplankton tows. The bridle of the zooplankton net was clipped to the tow cable of the ichthyoplankton net. Upon release, it ran down the cable to deploy above the top edge of the ichthyoplankton net. The zooplankton net was deployed and retrieved manually by its tow line. To avoid contamination during deployment and retrieval, a second line was looped around the collar of the net, which closed off the cod end. The loop was released when the net was in position.

Table 2. Sillaginodes punctata. Total number and mean density with respect to depth for sampling in 1996. N: number of replicate hauls per depth. S: surface; $M$ : mid; D: deep; B: bottom

\begin{tabular}{|c|c|c|c|c|c|c|c|c|c|c|c|}
\hline \multirow[t]{2}{*}{ Site } & \multirow[t]{2}{*}{ Date } & \multirow[t]{2}{*}{$\begin{array}{l}\text { Diurnal } \\
\text { state }\end{array}$} & \multirow[t]{2}{*}{$N$} & \multicolumn{4}{|c|}{ Number } & \multicolumn{4}{|c|}{$\begin{array}{l}\text { Mean density per haul } \\
\quad\left(\text { no. } 1000 \mathrm{~m}^{-3} \text { ) }\right.\end{array}$} \\
\hline & & & & S & M & D & B & S & $M$ & $\mathrm{D}$ & B \\
\hline PJ1 & $17 \mathrm{Sep}$ & Day & 2 & 2 & 0 & 0 & 0 & 1.58 & 0 & 0 & 0 \\
\hline PJ1 & $2 \mathrm{Oct}$ & Day & 2 & 6 & 0 & 0 & 0 & 2.51 & 0 & 0 & 0 \\
\hline PJ1 & $13 \mathrm{Oct}$ & Day & 3 & 7 & 0 & 0 & 0 & 2.43 & 0 & 0 & 0 \\
\hline PJ1 & $20 \mathrm{Oct}$ & Night & 3 & 6 & 8 & 8 & 10 & 2.32 & 3.07 & 3.27 & 4.14 \\
\hline PJ1 & 21 Oct & Night & 3 & 0 & 0 & 2 & 2. & 0 & 0 & 0.85 & 0.90 \\
\hline PJ1 & 12 Nov & Day & 3 & 0 & 0 & 0 & 0 & 0 & 0 & 0 & 0 \\
\hline SL4 & 23 Sep & Day & 2 & 0 & 0 & 0 & 0 & 0 & 0 & 0 & 0 \\
\hline PN1 & 27 Sep & Day & 2 & 4 & 0 & 0 & 0 & 4.58 & 0 & 0 & 0 \\
\hline PA.1 & $80 \mathrm{ct}$ & Day & 3 & 1 & 0 & 0 & 0 & 0.62 & 0 & 0 & 0 \\
\hline PA1 & $25 \mathrm{Oct}$ & Day & 3 & 1 & 0 & 0 & 0 & 0.39 & 0 & 0 & 0 \\
\hline$P \perp 1$ & $31 \mathrm{Oct}$ & Day & 3 & 0 & 0 & 0 & 0 & 0 & 0 & 0 & 0 \\
\hline
\end{tabular}


Treatment of samples. Upon retrieval, the nets were washed down with seawater, and the contents of the cod end emptied onto a sieve $(1 \mathrm{~mm}$ mesh for ichthyoplankton, $253 \mu \mathrm{m}$ for zooplankton). The sieved material was immediately preserved in $95 \%$ ethanol. Ethanol was replaced within $6 \mathrm{~h}$ from when the haul was made, and thence every 10 to $14 \mathrm{~d}$ until sorted.

Ichthyoplankton samples were sorted in a plastic tray under an illuminated magnifier $(5 \times$ magnification). All Sillaginodes punctata larvae were separated out and counted. S. punctata larvae from ichthyoplankton samples taken concurrently with zooplankton sampling had their gut contents analysed. The guts of specimens from 4 night-time sampling trips $(6,8,15$ and 24 October 1995) were also analysed. Specimens were placed in a drop of glycerol on a microscope slide, and the entire length of the gut was dissected from the specimens using electrolytically sharpened tungsten needles. Prey items were counted and identified to the lowest taxonomic level possible (generally Order or Suborder).

Zooplankton samples were stained with Rose Bengal and then sorted under a binocular dissecting microscope. Plankters were generally identified to Order or Suborder, and to developmental stage for larval forms. When more than approximately 150 of the more common taxa were present in a sample, the sample was halved once or more using a Folsom plankton splitter. The resulting subsample was sorted, and the remainder proportionally assigned to the groups present. The smallest subsample sorted was $1 / 32$.

Data analysis. Abundances of Sillaginodes punctata were standardised to number per $1000 \mathrm{~m}^{3}$ (mean volume sampled was $477 \mathrm{~m}^{3}$ ) and plankton abundance data were standardised to number per $\mathrm{m}^{3}$. Box and probability plots of $S$. punctata and zooplankter abundance data and model residuals were examined to assess normality and homogeneity of variance in the data. These plots showed a need for $\log (x+1)$ transformation. Proportions of larval densities were also analysed to reduce the influence of day to day variation in abundance; these data were arcsine transformed. To satisfy the assumptions of analysis of variance of $S$. punctata densities in 1995 it was necessary to omit the data from 2 October, because only 1 larva was collected on this date.

Variation in density of Sillaginodes punctata was analysed with a partially nested design, with day nested within time of day and tide, and orthogonal with depth. Replicates were averaged to simplify the analysis as they were used to test only the day by time of day by depth by tide interaction, in which we had little interest. For the analysis of proportions, the data for the middle layer were omitted, so the means were not limited to a sum of 1.0 (which would make the data non-independent). For the zooplankton data, 4 taxa were chosen for analysis: copepods, decapod zoeae, carid myses and euphausiid calyptopes. A similar partially nested analysis was performed on these logtransformed densities, with day nested within tide and orthogonal with depth. Time of day, tide and depth were treated as fixed factors while day was treated as a random factor. Variance components were approximated using the method described by Sokal \& Rohlf (1981). Statistical analyses were carried out with the Systat 5.2 computer programs (Wilkinson et al. 1992).

To determine the relative importance of each prey type in the diet of the larvae dissected, an index was calculated that was the product of $F$ (percent frequency of occurrence in larval guts) and $N$ (percent of total number of items in the diet) (Govoni et al, 1983). This index was compared across the 4 sampling days.

\section{RESULTS}

A total of 1024 Sillaginodes punctata larvae were collected at BWS1 in 1995 (Table 1). Abundance of $S$. punctata larvae varied significantly with depth and time of day, with larvae concentrated near the surface during daylight but showing a relatively even distribution at night (Table 3, Fig. 2). The interaction of depth and time of day was also significant when proportions of larvae in the surface and bottom samples were analysed (Table 4, Fig. 3). There was no significant interaction between depth and tide when abundance data was analysed (Table 3 ), but there was a significant interaction when between-day variation in abundance was removed by analysing proportions, with larvae significantly closer to the surface on flood tides (Table 4, Fig. 3). Approximate variance components, however, indicated that the depth by tide interaction. only explained $6 \%$ of the total variance, compared with $57 \%$ for the interaction between time of day and

Table 3. Sillaginodes punctata. Partially nested analysis of variance of log-transformed density of pre-settlement individuals with respect to depth, day/night and tide over $16 \mathrm{sam}$ pling dates

\begin{tabular}{|lrrrr|}
\hline Source & df & MS & \multicolumn{1}{c|}{$F$} & \multicolumn{1}{c|}{$p$} \\
\hline Day/night & 1 & 37.60 & 40.63 & $<0.001$ \\
Tide & 1 & 2.98 & 3.22 & 0.098 \\
Day/night $\times$ Tide & 1 & 2.40 & 2.59 & 0.133 \\
Day(Day/night $\times$ Tide) & 12 & 0.93 & 2.90 & 0.013 \\
Depth & 2 & 5.47 & 17.21 & $<0.001$ \\
Depth $\times$ Day/night & 2 & 3.91 & 12.30 & $<0.001$ \\
Depth $\times$ Tide & 2 & 1.01 & 3.18 & 0.060 \\
Depth $\times$ Tide $\times$ Day/night & 2 & 0.29 & 0.92 & 0.393 \\
Error & 24 & 0.32 & & \\
\hline
\end{tabular}




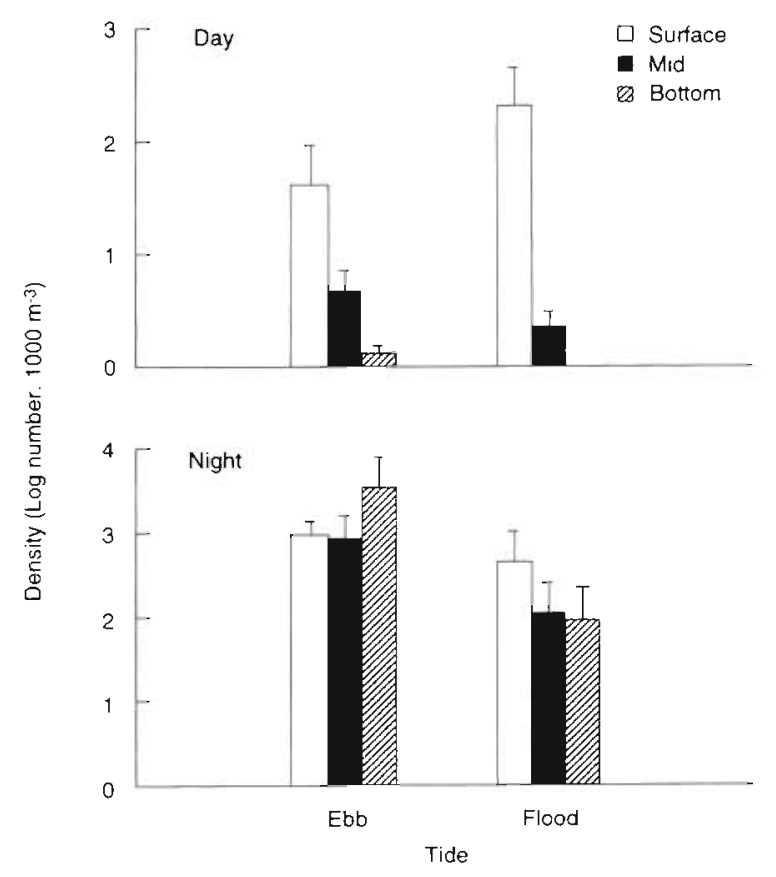

Fig. 2. Sillaginodes punctata. Log-transformed densities of pre-settlement individuals in 1995 at 3 depths with respect to stage of tide and day or night. Error bars are standard error

depth. Overall, significantly greater numbers of larvae were collected at night, and the day/night difference in abundance was the other major source of variation, explaining approximately $30 \%$ of the overall variation in larval densities (Tables 3 \& 4).

In 1996, a total of 51 Sillaginodes punctata larvae were collected at PJ1 whilst few larvae were collected at the other sites (Table 2). All larvae collected during daytime were collected in the surface sample. Significant numbers of larvae were collected at night at PJ1 and these had a relatively even distribution through the water column (Fig. 4).

Table 4. Sillaginodes punctata. Partially nested analysis of variance of arcsine-transformed mean proportion of presettlement individuals in surface and bottom depths, with respect to day/night and tide over 16 dates

\begin{tabular}{|lrrrr|}
\hline Source & di & MS & \multicolumn{1}{c|}{$F$} & \multicolumn{1}{c|}{$p$} \\
\hline Day/night & 1 & 0.30 & 8.57 & 0.013 \\
Tide & 1 & 0.03 & 0.75 & 0.404 \\
Day/night $\times$ Tide & 1 & 0.04 & 1.19 & 0.298 \\
Day (Day/night $\times$ Tide) & 12 & 0.04 & 0.74 & 0.691 \\
Depth & 1 & 2.70 & 57.07 & $<0.001$ \\
Depth $\times$ Day/night & 1 & 2.22 & 46.93 & $<0.001$ \\
Depth $\times$ Tide & 1 & 0.37 & 7.92 & 0.016 \\
Depth $\times$ Tide $\times$ Day/night & 1 & 0.05 & 1.00 & 0.337 \\
Error & 12 & 0.05 & & \\
\hline
\end{tabular}

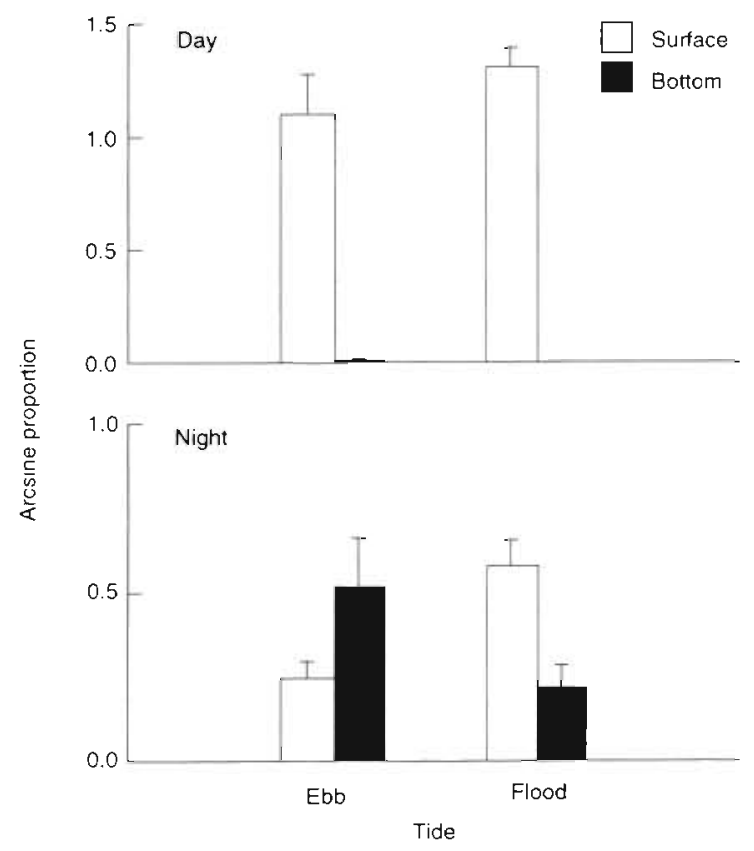

Fig. 3. Sillaginodes punctata. Arcsine-transformed proportions of pre-settlement individuals in 1995 in surface and bottom samples with respect to stage of tide and day or night. Error bars are standard error

A total of 137 Sillaginodes punctata larvae collected in 1995 were dissected for gut analysis, 99 from daytime and 38 from night-time sampling. For daytime samples, only 7 larvae from depths other than the surface were available, so these individuals were omitted from the analysis. For night-time samples, specimens from all depths were selected. Of the larvae collected at night only 4 had prey items in the gut. These larvae came from 2 hauls that started within 30 min after the onset of darkness. By contrast, only 2 larvae from daytime samples had no prey in their guts.

The diet of larvae collected in daytime, in terms of frequency of occurrence and percentage of prey number, was dominated by copepods (predominantly calanoids), and to a lesser extent carid myses, on 3 of the 4 dates. However, on 8 November, the diet was dominated by calyptopes, with copepods also important (Table 5). Mean prey number per gut on 3 and 8 November was approximately double that on 26 October and 16 November (Table 5).

Analysis of variance indicated that there was little variation in the depth distribution of the major zooplankton taxa found in Sillaginodes punctata guts (Table 6. Fig. 5). Only zoeae showed significant variation with depth, with generally lower concentrations near the surface (Table 6, Fig. 5), while calyptopes showed a significant interaction between depth and tide, with individuals near the surface during ebb tide 


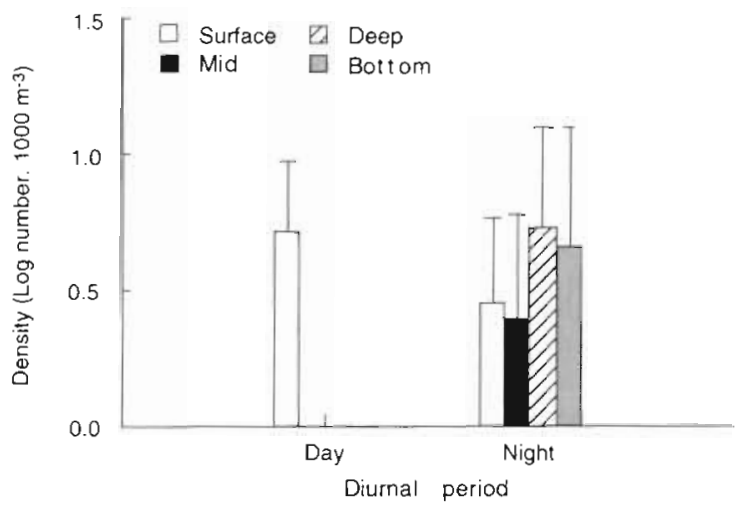

Fig. 4. Sillaginodes punctata. Log-transformed densities of pre-settlement individuals in 1996 at 4 depths with respect to day or night. Error bars are standard error

on 3 and 16 November (Table 6, Fig. 5). Variation in the diet of $S$. punctata was reflected to a large extent by the composition of the zooplankton. Copepods dominated the zooplankton with the exception of samples taken on 8 November, when calyptopes occurred in very high concentrations (Fig. 5). This was reflected in the significant variation between days within tides for calyptopes (Table 6). The other taxon to show a significant variation amongst days was zoeae, which decreased in abundance over time (Table 6, Fig. 5).
Zoeae in the plankton were under-represented in the diet (Table 5).

\section{DISCUSSION}

Sillaginodes punctata larvae showed pronounced vertical migration in relation to the day/night cycle. Larval whiting, like larvae of many fish species, show a form of 'reverse' diurnal migration (Boehlert et al. 1985, Yamashita et al. 1985, Sogard et al. 1987, Neilson \& Perry 1990, Heath et al. 1991, Lyczkowski-Shultz \& Steen 1991), specifically, stratification near the surface during the day, and random distribution or 'nocturnal diffusion' at night (Brewer \& Kleppel 1986, Davis et al. 1990, Leis 1991, Haldorson et al. 1993). All larvae collected in Port Phillip Bay were relatively large (15 to $20 \mathrm{~mm}$ ) and competent to settle (Jenkins \& May 1994). Vertical migratory behaviour generally becomes stronger with development (Neilson \& Perry 1990, Heath et al. 1991, Champalbert \& Koutsikopoulos 1995); therefore, migration in younger larvae may be less pronounced than in the late-larval stage we investigated.

The reverse diurnal migration seemed even more pronounced at deeper stations in 1996, although the sample size was much smaller compared with 1995.

Table 5. Sillaginodes punctata. Diet of pre-settlement individuals in 1995 expressed as percent frequency of occurrence $(F)$ and percent of total number $(N)$ of prey in the diet, and the product $(F \times N)$ that was taken as an index of relative importance

\begin{tabular}{|c|c|c|c|c|c|c|c|c|c|c|c|c|}
\hline \multirow[t]{2}{*}{ Taxon } & \multicolumn{3}{|c|}{$\begin{array}{c}26 \text { October } \\
(n=35)\end{array}$} & \multicolumn{3}{|c|}{$\begin{array}{c}3 \text { November } \\
(\mathrm{n}=29)\end{array}$} & \multicolumn{3}{|c|}{$\begin{array}{c}8 \text { November } \\
(n=10)\end{array}$} & \multicolumn{3}{|c|}{$\begin{array}{l}16 \text { November } \\
(n=25)\end{array}$} \\
\hline & $F$ & $N$ & $F \times N$ & $F$ & $N$ & $F \times N$ & $F$ & $N$ & $F \times N$ & $F$ & $N$ & $F \times N$ \\
\hline Copepods & 77 & 62 & 4774 & 52 & 46 & 2392 & 40 & 19 & 760 & 88 & 67 & 5896 \\
\hline Nauplii & 6 & 2 & 12 & 31 & 20 & 620 & 10 & 1 & 10 & 40 & 15 & 600 \\
\hline Carid myses & 37 & 28 & 1036 & 69 & 24 & 1656 & 20 & 3 & 60 & 36 & 13 & 468 \\
\hline Calyptopes & 0 & 0 & 0 & 7 & 1 & $?$ & 90 & 77 & 6930 & 4 & 1 & 4 \\
\hline Zoeae & 9 & 3 & 27 & 7 & 2 & 14 & 0 & 0 & 0 & 12 & 3 & 36 \\
\hline Other & 3 & 1 & 3 & 14 & 7 & 98 & 0 & 0 & 0 & 0 & 0 & 0 \\
\hline $\begin{array}{l}\text { Mean prey number } \\
\text { per larva }\end{array}$ & \multicolumn{3}{|c|}{3.3} & \multicolumn{3}{|c|}{7.1} & \multicolumn{3}{|c|}{7.7} & \multicolumn{3}{|c|}{3.7} \\
\hline
\end{tabular}

Table 6. Partially nested analysis of variance of log-transformed zooplankton density with respect to tide and depth for the different taxa. ${ }^{n s} p>0.05, \cdot p<0.05, \cdots p<0.001$

\begin{tabular}{|c|c|c|c|c|c|c|c|c|c|c|c|}
\hline \multirow[t]{2}{*}{ Source } & \multirow[t]{2}{*}{$\mathrm{df}$} & \multicolumn{2}{|c|}{ Copepods } & \multicolumn{2}{|c|}{ Calyptopes } & \multicolumn{2}{|c|}{ Myses } & \multicolumn{2}{|c|}{ Zoeae } & \multicolumn{2}{|c|}{ Total } \\
\hline & & $\mathrm{MS}$ & $F$ & $\mathrm{MS}$ & $F$ & MS & $F$ & MS & $F$ & MS & $F$ \\
\hline Tide & 1 & 4.84 & $4.35^{\mathrm{ns}}$ & 77.15 & $1.35^{\mathrm{ns}}$ & 1.60 & $0.38^{\mathrm{ns}}$ & 0.45 & $0.08^{\text {ns }}$ & 5.54 & $2.83^{\mathrm{ns}}$ \\
\hline Day(Tide) & 2 & 1.11 & $6.94^{\mathrm{ns}}$ & 57.13 & $317.39 \cdots$ & 4.22 & $2.08^{\mathrm{ns}}$ & 5.84 & $20.13^{\circ}$ & 1.96 & $9.8^{n s}$ \\
\hline Depth & 2 & 0.27 & $1.72^{\mathrm{ns}}$ & 0.03 & $0.17^{\mathrm{ns}}$ & 0.67 & $0.33^{115}$ & 3.78 & $13.15^{\circ}$ & 0.67 & $3.31^{\mathrm{ns}}$ \\
\hline Depth $\times$ Tide & 2 & 0.54 & $0.55^{\mathrm{ns}}$ & 1.53 & $8.55^{\circ}$ & 1.77 & $0.87^{\mathrm{ns}}$ & 0.48 & $1.65^{\mathrm{ns}}$ & 0.09 & $0.47^{\mathrm{ns}}$ \\
\hline Error & 4 & 0.16 & & 0.18 & & 2.03 & & 0.29 & & 0.20 & \\
\hline
\end{tabular}


Although reasonable numbers of larvae were collected at 1 deeper site near Port Phillip Heads, at other sites they were very rare. The difference in catch between years probably reflected spatial variability. Plankton sampling at 20 sites in the southern half of Port Phillip Bay over 2 yr has shown that larvae are more concentrated in shallow, nearshore waters of the bay, and site BWS1 had by far the greatest abundance of larvae (G. Jenkins unpubl. data).

The strong diurnal variation in gut contents, indicating that feeding only occurs in daylight, may suggest that diurnal migration observed in Sillaginodes punctata larvae is an adaptive response to maximise feeding. In some studies, vertical migratory behaviour has been linked to the vertical distribution of prey (Fortier \& Leggett 1983, Munk et al. 1989, Neilson \& Perry 1990. Haldorson et al. 1993); however, in a number of species, including $S$. punctata in this study, no relationship could be found between diurnal ascent/nocturnal diffusion and prey distribution (Yamashita et al. 1985, Brewer \& Kleppel 1986, Lyczkowski-Shultz \& Steen 1991). Because fish larvae are visual feeders (Blaxter 1986), the migratory behaviour observed in many species might simply be a response to finding optimum light levels for detection of prey. The threshold of light intensity that initiates vertical migration in fish larvae may be similar to that required for feeding (Blaxter 1986).

Another form of vertical migratory behaviour that was apparent for late-larval Sillaginodes punctata was in response to tide, although this effect was very minor and was only detectable when variation in abundance amongst days was removed. Such tidal migration, often termed selective tidal transport (Boehlert \& Mundy 1988), has been detected in a number of species, and is suggested to assist with transport of larvae to nearshore habitats, or retention in habitats such as estuaries (Weinstein et al. 1980, Fortier \& Leggett 1983, Rijnsdorp et al. 1985, Holt et al. 1989). Such behaviour might assist $S$. punctata larvae to reach habitats deep within bays and inlets. However, in most cases, this behaviour is strongly developed (Boehlert \& Mundy 1988), in contrast to the situation with larval $S$. punctata. Tidal migration in $S$. punctata larvae may not be an adaptation for transport, but rather a consequence of other factors, and may be a localised phenomenon at the site examined. For example, changes in the physical characteristics of the water column, such as water chemistry, temperature, salinity, hydrostatic pressure and turbulence, can influence vertical position (Heath et al. 1988, Heath et al. 1991, De Vries et al. 1995a, b). Such factors might vary between ebb and flood tide, and therefore influence vertical position tidally. Any factor leading to larvae occurring closer to the surface on a flood tide, whether passive or active, would tend
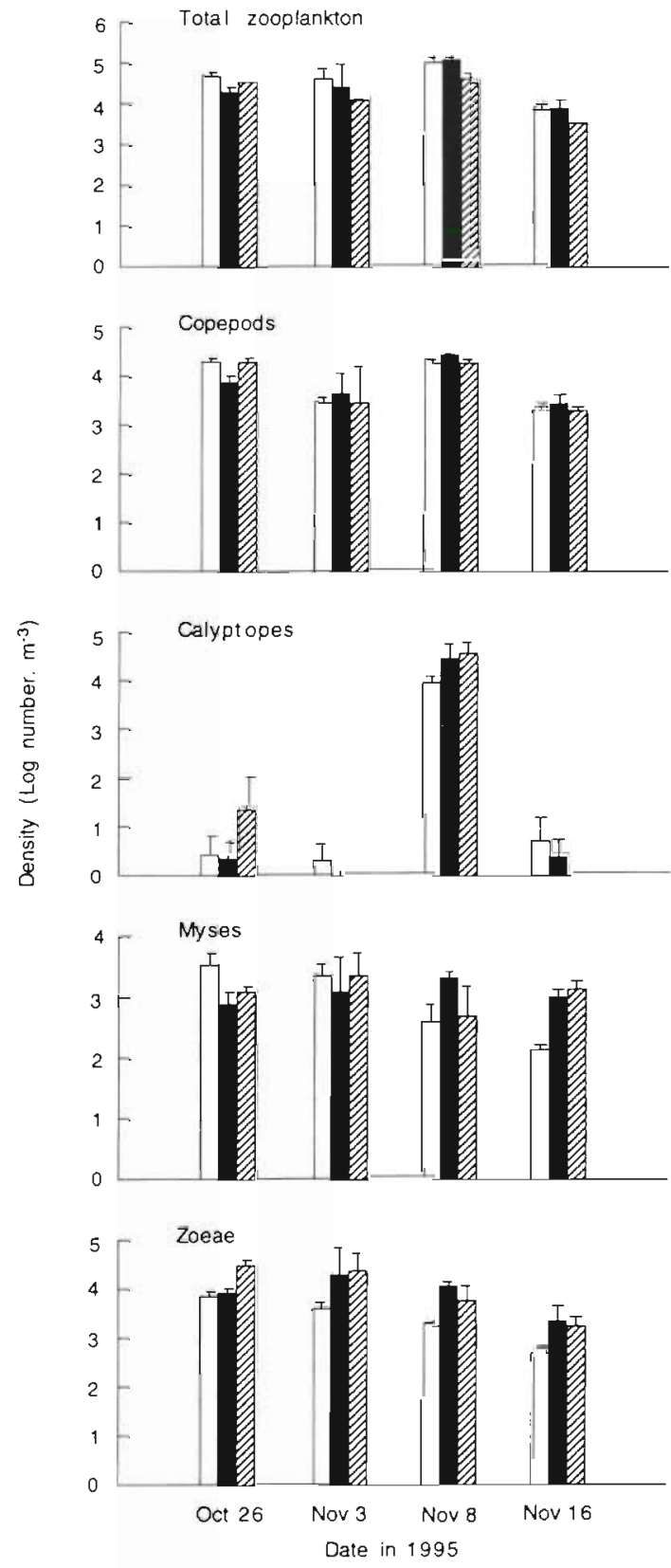

$\square$ Surface $\square$ Mid $Z$ Bottom

Fig. 5. Log-transformed density of total zooplankton, and common individual taxa, with respect to depth on 4 sampling dates. Error bars are standard error

to facilitate transport into, or retention within, Port Phillip Bay.

Apart from diurnal variation in vertical distribution, the other major source of variation in the analysis related to a greater abundance of larvae collected at night compared to daytime. The collection of greater numbers of fish larvae at night is a common phenomenon and is usually attributed to greater net avoidance 
during daytime (Bridger 1956, Brander \& Thompson 1989, Davis et al. 1990). Net avoidance during the day is probably more pronounced in larger larvae (Bridger 1956, Brander \& Thompson 1989). If net avoidance was significant during the day in our study, then the pattern of stratification we found would be conservative relative to the actual pattern, because net avoidance would be expected to be greater near the surface where more light was available.

The diet of larvae during the day largely reflected the availability of prey in the water column, as was well demonstrated when high abundances of calyptopes occurred both in the plankton and in the diet of larvae on 1 sampling date. An exception, however, was the small proportion of zoeae in the diet relative to their abundance in the water column. This relatively low representation in the diet might relate to the fact that zoeae were more concentrated deeper in the water column, although other factors such as strong spination that might deter predators or strong escape response may also have been important.

The observed vertical migratory behaviour has strong implications for transport of Sillaginodes punctata larvae to seagrass habitats. The southern part of Port Phillip Bay is tidally dominated; however, once north of the 'Sands' region, the circulation is largely wind driven and vertical variation in current strength would be high (Black et al. 1993). In terms of diurnal variation in vertical distribution, larvae concentrated near the surface during the day will be transported much faster than those deeper in the water column, and there is potential for larvae to reach habitats throughout the bay very quickly. If the tidal migration is a general phenomenon, then this may serve to direct movement up the bay, because tidal currents are generally stronger near the surface (Black et al. 1993). However, in the northern part of the bay, wind-driven currents would be expected to overwhelm tidal currents, and therefore the effect of selective tidal transport would be reduced. The potential for vertical tidal migration to influence transport in Port Phillip Bay seems weaker than in systems such as estuaries where countercurrents can exist at depth (Boehlert \& Mundy 1988), or in species where individuals can cling to the substrate on ebb tides (Creutzberg 1961, Rowe \& Epifanio 1994); however, the effect may be significant in terms of transporting larvae to potential juvenile habitats deep within the bay.

In conclusion, our study shows that in the shallow water of Port Phillip Bay, late larvae of King George whiting are found near the surface in the daytime and dispersed through the water column at night. This pattern is not related to the vertical distribution of prey but may have been a response to light for visual feeding. There is evidence of a change in vertical distribu- tion in relation to tide where larvae are closer to the surface on flood tides; however, any such migration is weak and may be spatially variable. These results may have significant implications for modelling of larval transport and recruitment (Jenkins \& Black 1994, Jenkins et al. 1997) whereby movement into the bay may be enhanced by tidal vertical migration and surface, wind-driven currents may lead to rapid transport of larvae within the bay during daytime.

Acknowledgements. Our thanks to Dr Kerry Black for his contributions to the development of this work. We thank Dr Jeff Leis and Dr Francisco Neira for helpf ul comments on the manuscript. This research was funded by the Australian Research Council and is a contribution from the Queenscliff Marine Station.

\section{LITERATURE CITED}

Anonymous (1973) Environmental study of Port Phillip Bay: report on Phase One 1968-71. Melbourne and Metropolitan Board of Works, Melbourne

Black KP. Hatton D, Rosenberg M (1993) Locally and externally-driven dynamics of a large semi-enclosed bay in southern Australia. J Coast Res 9:509-538

Black KP, Moran PJ (1991) Influence of hydrodynamics on the passive dispersal and initial recruitment of larvae of Acanthaster plancion the Great Barrier Reef. Mar Ecol Prog Ser 69:55-65

Blaxter JHS (1986) Development of sense organs and behaviour of teleost larvae with special reference to feeding and predator avoidance. Trans Am Fish Soc 115:98-114

Boehlert GW, Gadomski DM, Mundy BC (1985) Vertical distribution of ichthyoplankton off the Oregon coast in spring and summer months. Fish Bull 83:611-621

Boehlert GW, Mundy BC (1988) Roles of behavioural and physical factors in larval and juvenile fish recruitment to estuarine nursery areas. Am Fish Soc Symp 3:51-67

Brander K, Thompson AB (1989) Diel differences in avoidance of three vertical profile sampling gears by herring larvae. J Plankton Res 11:775-784

Brewer GD, Kleppel GS (1986) Diel vertical distribution of fish larvae and their prey in nearshore waters of southern California. Mar Ecol Prog Ser 27:217-226

Bridger JP (1956) On day and night variation in catches of fish larvae. J Cons Int Explor Mer 22:42-57

Chae J, Nishida S (1995) Vertical distribution and diel migration in the iridescent copepods of the family Sapphirinidae: a unique example of reverse migration? Mar Ecol Prog Ser 119:111-124

Champalbert G, Koutsikopoulos C (1995) Behaviour, transport and recruitment of Bay of Biscay sole (Solea solea): laboratory and field studies. J Mar Biol Assoc UK 75: 93-108

Creutzberg F (1961) On the orientation of migrating elvers (Anguilla vulgaris Turt) in a tidal area. Neth J Sea Res 1: $257-338$

Davis TLO, Jenkins GP, Young JW (1990) Diel patterns of vertical distribution in larvae of southern bluefin Thunnus maccoyii, and other tuna in the East Indian Ocean. Mar Ecol Prog Ser 59:63-74

De Vries MC, Forward RB Jr, Hettler WF (1995a) Behavioral response of larval Atlantic menhaden Brevoortia tyrannus 
(Latrobe) and spot Leiostomus xanthurus (Lacépède) to rates of salinity change. J Exp Mar Biol Ecol 185:93-108

De Vres MC, Forward RB Jr. Hettler WF (1995b) Behavioural response of larval Atlantic menhaden to different rates of temperature change. J Fish Biol 47:1081-1095

Fortier L, Leggett WC (1983) Vertical migrations and transport of larval fish in a partially mixed estuary. Can J Fish Aquat Sci 40:1543-1555

Fowler AJ, Short DA (1996) Temporal variation in the early life-hustory characteristics of the King George whiting (Slllaginodes punctata) from analysis of otolith microstructure. Mar Freshwat Res 47:809-818

Govoni JJ, Hoss DE, Chester AJ (1983) Comparative feeding of three species of larval fishes in the northern Gulf of Mexico: Brevoortia patronus, Leiostomus xanthurus, and Micropogonias undulatus. Mar Ecol Prog Ser 13:189-199

Haldorson L, Prichett M, Paul AJ, Ziemann D (1993) Vertical distribution and migration of fish larvae in a Northeast Pacific bay. Mar Ecol Prog Ser 101:67-80

Haney JF (1988) Diel patterns of zooplankton behaviour. Bull Mar Sci 43:583-603

Heath M, Brander K, Munk P, Rankine P (1991) Vertical distributions of autumn spawned larval herring (Clupea harengus L.) in the North Sea. Cont Shelf Res 11:1425-1452

Heath MR, Henderson EW, Baird DL (1988) Vertical distribution of herring larvae in relation to physical mixing and illumination. Mar Ecol Prog Ser 47:211-228

Holt SA, Holt GJ, Arnold CR (1989) Tidal stream transport of larval fishes into non-stratified estuaries. Rapp PV Réun Cons Int Explor Mer 191:100-104.

Hutchinson GE (1967) A treatise on limnology. Wiley and Sons, New York

Jenkins GP, Black KP (1994) Temporal variability in settlement of a coastal fish, the King George whiting, Sillaginodes punctata, is determined by low-frequency hydrodynamics. Limnol Oceanogr 39:1744-1754

Jenkins GP, Black KP. Wheatley MJ, Hatton DN (1997) Temporal and spatial variability in recruitment of a temperate, seagrass-associated fish is largely determined by physical processes in the pre- and post-settlement phases. Mar Ecol Prog Ser 148:23-35

Jenkins GP, May HMA (1994) Variation in settlement and larval duration of King George whiting, Sillaginodes punctata (Sillaginidae), in Swan Bay, Victoria, Australia. Bull Mar Sci 54:281-296

Jenkins GP, Wheatley MJ, Poore AGB (1996) Spatial variation in recruitment, growth and feeding of post-settlement King George whiting, Sillaginodes punctata, associated with seagrass beds of Port Phillip Bay, Australia. Can J Fish Aquat Sci 53:96-105

Kailola PJ, Williams MJ, Stewart PC, Reichelt RE, McNee A, Grieve $C$ (1993) Australian fisheries resources. Bureau of Resources Sciences and Fisheries Research and Development Corporation, Canberra

Kendall AW, Naplin NA (1981) Diel-depth distribution of summer ichthyoplankton in the Middle Atlantic Bight. Fish Bull 79:705-726

Keough MJ, Black KP (1996) Predicting the scale of marine

Editorial responsibility: Otto Kinne (Editor), Oldendorf/Luhe, Germany impacts: understanding planktonic links between populations. In: Schmitt RJ, Osenberg CW (eds) The design of ecological impact studies: conceptual issues and application in coastal marine habitats. Academic Press, Orlando, p $199-234$

Kingsford MJ (1990) Linear oceanographic features: a focus for research on recruitment processes. Aust J Ecol 15:391-401

Leis JM (1991) Vertical distribution of fish larvae in the Great Barrier Reef Lagoon, Australia. Mar Biol 109:157-166

Lyczkowski-Shultz J, Steen JP Jr (1991) Diel vertical distribution of red drum Sciannops ocellatus larvae in the northcentral Gulf of Mexico. Fish Bull 89:631-641

McShane PE, Black KP, Smith MG (1988) Recruitment processes in Haliotus rubra (Mollusca: Gastropoda) and regional hydrodynamics in southeastern Australia imply localized dispersal of larvae. J Exp Mar Biol Ecol 124: $175-205$

Mileikovsky SA (1973) Speed of active movement of pelagic larvae of marine bottom invertebrates and their ability to regulate their vertical position. Mar Biol 23:11-17

Munk P, Kiørboe T, Christensen V (1989) Vertical migrations of herring. Clupea harengus, larvae in relation to light and prey distribution. Environ Biol Fish 26:87-96

Neilson JD, Perry RI (1990) Diel vertical migrations of marine fishes: an obligate or facultative process? Adv Mar Biol 26: $115-168$

Ohman MD (1990) The demographic benefits of diel vertical migration by zooplankton. Ecol Monogr 60:257-281

Rijnsdorp AD, van Stralen M, van der Veer HW (1.985) Selective tidal transport of North Sea plaice larvae Pleuronectes platessa in coastal nursery areas. Trans Am Fish Soc 114 $461-470$

Rowe PM. Epifanio CE (1994) Tidal stream transport of weakfish larvae in Delaware Bay, USA. Mar Ecol Prog Ser 110: $105-114$

Scheltema RS (1986) On dispersal and planktonic larvae of benthic invertebrates: an eclectic overview and summary of problems. Bull Mar Sci 39:290-322

Smith WG, Sibunka JD, Wells A (1978) Diel movements of larval yellowtail flounder, Limanda ferruginea, determined from discrete depth sampling. Fish Bull 76:167-178

Sogard SM, Hoss DE, Govoni JJ (1987) Density and depth distribution of larval Gulf menhaden Brevoortia patronus, Atlantic croaker, Micropogonias undulatus, and spot, Leiostomus xanthurus, in the Northern Gulf of Mexico. Fish Bull 85:601-609

Sokal RR, Rohlf FJ (1981) Biometry. WH Freeman and Company, New York

Weinstein MP, Weiss SL, Hodson RG, Gerry LR (1980) Retention of three taxa of postlarval fishes in an intensively flushed tidal estuary, Cape Fear River, North Carolina. Fish Bull 70:419-436

Wilkinson L, Hill M, Vang E (1992) SYSTAT: statistics, version 5.2 edition. SYSTAT Inc, Evanston

Yamashita Y, Kitagawa D, Aoyama T (1985) Diel vertical. migration and feeding rhythm of the larvae of the Japanese sand-eel Ammodytes personatus. Bull Jpn Soc Sci Fish $51: 1-5$

Submitted: November 19, 1997; Accepted: July 2, 1998

Proofs received from author(s): July 29, 1998 